\title{
Nutritional value of lupin (Lupinus albus)-seed meal for growing pigs: availability of lysine, effect of autoclaving and net energy content
}

\author{
By E. S. BATTERHAM, L. M. ANDERSEN, R. F. LOWE \\ AND R. E. DARNELL* \\ Department of Agriculture, North Coast Agricultural Institute, Wollongbar, \\ New South Wales 2480, Australia
}

(Received 12 July 1985 - Accepted 23 June 1986)

\begin{abstract}
1. Two experiments were conducted to assess the nutritional value of lupin (Lupinus albus)-seed meal for growing pigs. In the first, the availability of lysine was assessed using slope-ratio analysis. In the second, the effects of autoclaving lupin seeds and formulating the diets on the basis of estimated digestible or net energy were assessed.

2. In the first experiment, the availability of lysine in three samples of lupin-seed meal was compared with that in meat-and-bone meal and soya-bean meal. Availability of lysine in the five protein concentrates, using food conversion efficiency on a carcass basis as the criterion of response, was (proportion of total): lupin-seed meal no. 10.44 , no. 20.57 , no. 30.53 , meat-and-bone meal 0.42 , soya-bean meal 0.80 .
\end{abstract}

3. Availability estimates, based on protein deposited: food intake, were: lupin-seed meal no. $10 \cdot 82$, no. $20 \cdot 73$, no. 30.70 , meat-and-bone meal 0.27 , soya-bean meal 0.77 . These estimates had higher standard deviations than those based on carcass response.

4. Regressing the measures of response $v$. lysine intake resulted in estimates of availability similar to, or higher than, the slope-ratio analysis but was associated with greater statistical invalidity and higher standard deviations.

5. The proportion of energy retained in the carcasses was unaffected by the inclusion levels of lysine or soya-bean meal. Energy retention was depressed $(P<0.05)$ with the three lupin-seed meals and the meat-and-bone meal.

6. In the second experiment, the response of pigs given a diet containing lupin-seed meal was inferior, on a carcass basis $(P<0.05)$, to that of pigs given a diet containing soya-bean meal formulated to similar total lysine and digestible energy contents.

7. The addition of soya-bean oil to the diet containing lupin-seed meal, to equalize the estimated net energy of the diet to that of the diet containing soya-bean meal, depressed protein deposition $(P<0.05)$ and increased fat deposition $(P<0.05)$, indicating that energy was not limiting the growth of pigs given the lupin-seed-meal diet.

8. Autoclaving the lupin-seed at $121^{\circ}$ for $5 \mathrm{~min}$ had no effect on the growth of pigs, indicating that the low availability of lysine was not due to the presence of heat-labile anti-nutritional factors.

Cultivars of Lupinus angustifolius have been shown to have a low lysine availability $(0.55$; proportion of total) for growing pigs (Batterham et al. 1984). This low availability is specific to pigs as it is high in rats $(0.82$; Batterham et al. 1984) and chicks $(0.89$; E. J. Major and E. S. Batterham, unpublished results). The low availability for pigs is not related to impaired digestibility as the digestibility of lysine at the terminal ileum is high $(0.93$; Taverner et al. 1983), nor does it appear to be related to alkaloid content (Batterham et al. 1984) or the presence of heat-labile anti-nutritional factors (Batterham et al. 1986a).

The availability of lysine in cultivars of Lupinus albus has not been determined. The ileal digestibility of lysine is high (about 0.82 ; Taverner, 1982). However, high rates of inclusion of $L$. albus in diets for growing pigs have been associated with depressed pig performance (Batterham, 1979; King, 1981; Taverner, 1982). It is not known whether this is due to low amino acid availability or to the presence of anti-nutritional factors. Although $L$. albus is a manganese accumulator, high Mn levels do not appear to be the reason for the growth depression associated with its use (King, 1981).

\footnotetext{
* Present address: Agricultural Research and Advisory Station, Grafton, New South Wales 2460, Australia.
} 
Although the ileal digestibility by pigs of lysine and other amino acids in both $L$. angustifolius and L.albus is high, the ileal digestibility of dry matter and energy is low (about 0.50; Taverner, 1982; Taverner \& Curic, 1983; Taverner et al. 1983). However, the overall digestibility of dry matter and energy is high (about 0.85 ) as a considerable proportion is digested in the hind-gut (Taverner, 1982; Taverner \& Curic, 1983; Taverner et al. 1983), presumably involving the microbial production of volatile fatty acids and their absorption through the wall of the hind-gut. This is thought to result in a lower net energy absorption than when the energy is absorbed as carbohydrates and triglycerides in the small intestine (Just et al. 1983). As a consequence, Taverner et al. (1983) estimated that, while 0.67 of the digestible energy in wheat was available as net energy, for lupin-seed meal the proportion was only 0.55. As the diets for the slope-ratio assays for L. angustifolius (Batterham et al. 1984) and for other production experiments (Batterham, 1979; King, 1981; Taverner, 1982) were formulated on a digestible energy basis, it is possible that the net energy in these diets may have been lower and this may have contributed to the lower performance of the pig.

The net energy of diets can be assessed by determining the amounts of energy deposited in the carcasses of growing pigs that have similar growth rates, so that the maintenance energy component is similar for all diets. With slope-ratio assays, growth rate increases with increasing lysine dose and, therefore, the net energy of the diet may increase. However, the slopes of the responses of energy deposition $v$. lysine dose should be similar if the net energy contents of the diets containing the test proteins are the same as the diets used to determine the standard lysine response. This could be assessed by determining the amount of energy deposited during the slope-ratio assay.

In previous slope-ratio assays with growing pigs, food conversion efficiency (FCE) on a carcass basis was found to be the most appropriate criterion of response as it took into account both differences in food intake and gut contents (Batterham et al. 1979, 1981, 1984). In using carcass gain as a response criterion it is assumed that lean deposition is similar with increasing dose level. This was verified by assessing the lean content of the hams of pigs used in the slope-ratio assays. However, in the results of Batterham et al. (1984), although there were no significant differences in the slopes of lean deposition for pigs fed on the test proteins and the standard lysine response, there was a small difference between the slopes of two of the protein concentrates (cottonseed meal and soya-bean meal). This difference may have been due to chance, or it may reflect differences between the two protein concentrates, in which case total lean (protein) deposition may be a more sensitive measure of response than carcass gain.

Availability estimates for previous assays have been calculated using the slope-ratio analysis of Finney (1964). With this analysis, the response is regressed $v$. lysine dose level. Some assays with some meals (for example, see Batterham et al. 1984) were statistically invalid. An alternative analysis is to regress the response $v$. lysine intake (Carpenter, 1973; Cave \& Williams, 1980). This is a slightly more complicated analysis, but Cave \& Williams (1980) reported fewer problems with fundamental invalidity using this method compared with the Finney (1964) method.

The present paper reports two experiments. The objectives of the first were to determine the availability of lysine in three samples of $L$. albus using the slope-ratio assay with growing pigs, and to determine the amounts of energy and protein deposited in the pigs' carcasses. The efficiency of energy utilization was estimated to determine whether the net energy of the diets containing lupin-seed meal was lower than that of the standard lysine diets. Protein deposition was estimated to determine whether availability estimates based on this measurement were more sensitive than those based on carcass gain. For comparative purposes, the availability of lysine in meat-and-bone meal and soya-bean meal was also determined. Availability estimates were calculated by both the slope-ratio analysis and by 
regressing the measure of response $v$. lysine intake. In the second experiment, the effects of formulating diets on either an estimated digestible energy or a net energy basis and of autoclaving the lupin seed were investigated. These treatments were designed to determine whether a deficiency of net energy or the presence of heat-labile anti-nutritional factors was responsible for the low estimates of lysine availability in lupin-seed meal.

\section{EXPERIMENTAL}

\section{Protein concentrates}

The compositions of the wheat, wheat gluten and the five protein concentrates are presented in Table 1. The lupin-seed meals were either Hamburg (nos. 1 and 2) or Ultra (no. 3) cultivars and were coarsely crushed through a hammer mill. The soya-bean meal was 'prepress' solvent extracted.

\section{Expt 1. Slope-ratio assay for lysine availability}

For the slope-ratio assays, diets were formulated to contain graded levels of free lysine or lysine supplied by the test ingredients. Linear regression coefficients of response (say FCE) to increasing dose level of test protein and standard lysine were calculated, and the linear regression coefficient ratio, test protein: standard lysine, provided an estimate of the potency of the lysine in the test protein.

Diets. The five protein concentrates were assayed in one experiment. This involved the use of thirty-one diets: the basal diet (blanks), five diets to determine the pigs' response to standard lysine and five for each protein concentrate. The basal diet contained $(\mathrm{g} / \mathrm{kg}):$ wheat 650 , wheat gluten 100 , L-lysine monohydrochloride $2 \cdot 05$, L-tryptophan $0 \cdot 3$, mineral and vitamin premix $6 \cdot 75$, bone meal 30 , Solkafloc 38 , soya-bean oil 25 , wheat starch $147 \cdot 9$. The wheat was of medium protein which, in combination with the wheat gluten, supplied adequate quantities of all the amino acids except lysine which was added to bring the basal level up to $5 \cdot 2 \mathrm{~g} / \mathrm{kg}$, and tryptophan which was added as a precaution. The six levels of lysine used to determine the pigs' response to standard lysine were in 500-mg increments of L-lysine $/ \mathrm{kg}$ and were provided by the addition to the basal diet of L-lysine monohydrochloride, anhydrous, $98 \%$ pure, supplied by Ajinomoto Co. Inc., Japan. The protein concentrates were incorporated into the diets at five inclusion levels $(40-200 \mathrm{~g} / \mathrm{kg}$ for the lupin-seed meal, and $20-100 \mathrm{~g} / \mathrm{kg}$ for the meat-and-bone meal and soya-bean meal) at the expense of wheat starch. The mineral and vitamin premix contributed $(\mathrm{mg} / \mathrm{kg}$ diet $)$ : iron 60 , zinc 100 , manganese 30 , copper 5 , iodine 2 , selenium $0 \cdot 15$, sodium chloride $2 \cdot 8 \mathrm{~g}$, potassium $0.6 \mathrm{~g}$, retinol equivalent $960 \mu \mathrm{g}$, cholecalciferol $12 \mu \mathrm{g}, \alpha$-tocopherol 20 , thiamin $1 \cdot 5$, riboflavin 3 , nicotinic acid 14 , pantothenic acid 10 , pyridoxine $2 \cdot 5$, cyanocobalamin $15 \mu \mathrm{g}$, pteroylmonoglutamic acid 2 , choline 500 , ascorbic acid 10 , biotin $0 \cdot 1$, olaquindox 25.

The digestible energy content of the protein concentrates and dietary components was estimated using results of previous determinations at this Agricultural Institute or values from the literature. Dietary energy was maintained at $14 \cdot 1 \mathrm{MJ} /$ digestible energy using wheat starch and soya-bean oil as non-protein energy sources.

Animals and procedures. The thirty-one diets were arranged in a randomized block design. The pigs were blocked on 7-week weight, sex and position in the experimental facilities. There were four blocks, two containing males and two females, all of the Large White breed. The pigs were penned individually and water was supplied by 'nipple' drinkers. Dietary treatments were introduced when the pigs reached $20 \mathrm{~kg}$ live weight.

The diets were offered at a daily rate of $1000 \mathrm{~g}$ at $20 \mathrm{~kg}$ live weight, with $100 \mathrm{~g}$ increments 
Table 1. Composition $(\mathrm{g} / \mathrm{kg})$ of the wheat, wheat gluten and five protein concentrates

\begin{tabular}{|c|c|c|c|c|c|c|c|}
\hline & \multirow[b]{2}{*}{ Wheat } & \multirow[b]{2}{*}{$\begin{array}{l}\text { Wheat } \\
\text { gluten }\end{array}$} & \multicolumn{3}{|c|}{ Lupin (Lupinus albus)-seed meal } & \multirow[b]{2}{*}{$\begin{array}{l}\text { Meat-and- } \\
\text { bone meal }\end{array}$} & \multirow[b]{2}{*}{$\begin{array}{l}\text { Soya-bean } \\
\text { meal }\end{array}$} \\
\hline & & & $\begin{array}{l}\text { No. } 1 \text { (cv. } \\
\text { Hamburg) }\end{array}$ & $\begin{array}{l}\text { No. } 2(\mathrm{cv} \\
\text { Hamburg) }\end{array}$ & $\begin{array}{l}\text { No. } 3(\mathrm{cv} . \\
\text { Uitra) }\end{array}$ & & \\
\hline $\begin{array}{l}\text { Crude protein (nitrogen } \\
\times 6.25 \text { ) }\end{array}$ & 155 & 791 & 363 & 324 & 355 & 560 & 454 \\
\hline Dry matter & 907 & 924 & 922 & 898 & 930 & 965 & 893 \\
\hline $\begin{array}{l}\text { Light petroleum (b.p. } 40-60^{\circ} \text { ) } \\
\text { extract }\end{array}$ & 18 & - & 82 & 93 & 70 & 120 & 28 \\
\hline \multicolumn{8}{|l|}{ Fibre } \\
\hline $\begin{array}{l}\text { Crude } \\
\text { Neutral-detergent }\end{array}$ & 22 & - & $\begin{array}{l}111 \\
218\end{array}$ & $\begin{array}{l}120 \\
187\end{array}$ & $\begin{array}{l}121 \\
204\end{array}$ & - & $\begin{array}{r}43 \\
116\end{array}$ \\
\hline Ash & 14 & 5 & 52 & 41 & 34 & 260 & 70 \\
\hline Manganese & $一$ & - & $2 \cdot 4$ & $2 \cdot 7$ & $1 \cdot 8$ & - & - \\
\hline Alkaloids & - & - & $0 \cdot 14$ & $0 \cdot 13$ & $0 \cdot 08$ & 一 & - \\
\hline \multicolumn{8}{|l|}{ Essential amino acids } \\
\hline Threonine & $5 \cdot 4$ & 25 & 15 & 14 & 14 & 18 & 19 \\
\hline Valine & $7 \cdot 0$ & 32 & 14 & 13 & 13 & 20 & 18 \\
\hline Cystine & $4 \cdot 2$ & 26 & 6 & 6 & 5 & 8 & 12 \\
\hline Methionine & $2 \cdot 3$ & 13 & 3 & 2 & 2 & 7 & 5 \\
\hline Isoleucine & $5 \cdot 6$ & 30 & 16 & $1 \overline{5}$ & 15 & 15 & 19 \\
\hline Leucine & 11.0 & 59 & 26 & 26 & 25 & 29 & 33 \\
\hline Tyrosine & $5 \cdot 6$ & 32 & 17 & 16 & 16 & 11 & 16 \\
\hline Phenylalanine & $7 \cdot 0$ & 41 & 13 & 12 & 13 & 17 & 21 \\
\hline Histidine & 3.9 & 17 & 8 & 7 & 9 & 7 & 14 \\
\hline Lysine & $3 \cdot 7$ & 13 & 15 & 15 & 16 & 25 & 27 \\
\hline $\begin{array}{l}\text { Indirect FDNB-lysine } \\
\text { (proportion of total) }\end{array}$ & - & - & 0.96 & 0.93 & 0.96 & 0.80 & 0.93 \\
\hline
\end{tabular}

FDNB, fluorodinitrobenzene.

for each $2.5 \mathrm{~kg}$ increase in live weight. The pigs were fed eight times daily, at intervals of $3 \mathrm{~h}$, with an automatic feeder to ensure full utilization of added free amino acids (Batterham \& Murison, 1981). The food was offered dry. Rations were adjusted after the weekly weighings of the pigs.

The pigs were slaughtered after reaching a minimum weight of $45 \mathrm{~kg}$ and the hot eviscerated carcass weights were recorded. The carcasses were chilled overnight at $4^{\circ}$, then split. The left-hand side carcass was stored at $-15^{\circ}$, then ground, mixed, sampled and freeze-dried before chemical analyses.

Pig response was assessed in terms of daily live-weight gain, FCE, killing-out proportion, daily carcass gain, FCE on a carcass basis, fat, protein and energy contents of carcass, fat deposition/d, protein deposition/d and energy deposition/d, protein deposited:food intake, protein deposited:lysine intake and energy deposited:energy intake.

The following factors were used in the previously mentioned calculations. The factor of 0.69 was used to estimate carcass weight from initial live weight. This value was previously determined with five male and five female piglets slaughtered at $20 \mathrm{~kg}$ live weight. Energy retained as protein and fat was calculated from the chemical analysis of the carcass material 
using the factors 24.2 (Jordan \& Brown, 1970) and 39.6 (Burlacu et al. 1973) to convert protein $(\mathrm{kg})$ and fat $(\mathrm{kg})$ to $\mathrm{MJ}$ energy. The carcasses at the start of the experiment were assumed to have a fat content of $118 \mathrm{~g} / \mathrm{kg}$ (males) and $141 \mathrm{~g} / \mathrm{kg}$ (females), and a protein $(\mathrm{N} \times 6.25)$ content of $164 \mathrm{~g} / \mathrm{kg}$ (males) and $152 \mathrm{~g} / \mathrm{kg}$ (females). These values were estimated in four pigs of each sex previously slaughtered at $20 \mathrm{~kg}$ live weight.

Daily carcass gain, FCE on a carcass basis, protein deposited/d and protein deposited: food intake were regressed $v$. lysine dose level by the slope-ratio assay technique of Finney (1964) for multiple assays. Availability estimates and standard deviations were calculated.

The four measures of response were also regressed $v$. lysine intake and the results were analysed by the method of Campbell (1966). Standard deviations were determined according to Finney (1964).

The results for killing-out proportion and energy retained: digestible energy intake were regressed against lysine for each protein concentrate. These analyses were conducted to determine whether there was any effect of inclusion level of protein concentrate on these measures.

\section{Expt 2. Effect of autoclaving and energy supplementation}

Dietary components. The wheat, lupin-seed meal (no. 3) and soya-bean meal were as in Expt 1 .

For the heat treatments, lupin seed was placed to a depth of approximately $90 \mathrm{~mm}$ in wire trays and autoclaved at $121^{\circ}$ for $5 \mathrm{~min}$. The seed was then cooled, dried in a forced-draught oven at $70^{\circ}$ for $2 \mathrm{~h}$ to original air-dry weight. Both the autoclaved and unheated lupin seed were coarsely crushed through a hammer mill before incorporation into the diets.

Diets. The basal diet (Table 2) was formulated from wheat and lupin-seed meal to be lysine-deficient ( $8 \mathrm{~g}$ lysine $/ \mathrm{kg}$ ) and to contain $14.5 \mathrm{MJ}$ digestible energy $/ \mathrm{kg}$. All other essential amino acids were adequate, relative to the balance recommended by the Agricultural Research Council (1981), except for methionine which was added.

Soya-bean meal was used as a positive control (diet 5), and was formulated to a similar lysine and digestible energy content as diet 1.

The net energies of the lupin-seed and soya-bean meal diets were estimated to be 8.9 and $9.5 \mathrm{MJ} / \mathrm{kg}$. These values were based on estimated net energy:digestible energy values of $0.55,0.55$ and 0.67 for the lupin-seed and soya-bean meals and wheat respectively (Taverner $\&$ Curic, 1983). The diets were equalized for estimated net energy using soya-bean oil (net energy: digestible energy value estimated as $0.80 ; \mathrm{D}$. J. Farrell, personal communication). Assessment of performance. The five diets were arranged in a randomized block design. The pigs were blocked on 7-week weight, sex and position in the experimental facilities. There were ten blocks, five containing males and five females, all of the Large White breed. The pigs were penned individually. Introduction of treatments, frequency of feeding, feeding rates and assessment of performance were as for Expt 1.

Statistical analyses. The results were examined by analysis of variance. The responses to autoclaving and oil supplementation were analysed as a $2 \times 2$ factorial. The comparisons of individual dietary responses (diets 1-4) with soya-bean meal (diet 5) were assessed by least significant difference (LSD).

\section{Chemical analyses}

The techniques used were as reported by Batterham et al. (1984), except for fat in the carcass (Pettinati \& Swift, 1975), manganese (Association of Official Analytical Chemists, 1975) and total alkaloids (Priddis, 1983). 
Table 4. Expt 1. Carcass gain, carcass food conversion efficiency and protein deposited by pigs during the 20-45 kg growth phase when given the diets for the slope-ratio assay for lysine

\begin{tabular}{|c|c|c|c|c|c|c|}
\hline \multirow{3}{*}{$\begin{array}{c}\text { Lysine dose } \\
\text { no.* }\end{array}$} & \multicolumn{6}{|c|}{ Form of lysine addition } \\
\hline & \multirow{2}{*}{$\begin{array}{c}\text { Free } \\
\text { lysine }\end{array}$} & \multicolumn{3}{|c|}{ Lupin (Lupinus albus)-seed meal } & \multirow{2}{*}{$\begin{array}{c}\text { Meat-and-bone } \\
\text { meal }\end{array}$} & \multirow{2}{*}{$\begin{array}{l}\text { Soya-bean } \\
\text { meal }\end{array}$} \\
\hline & & no. 1 & no. 2 & no. 3 & & \\
\hline \multicolumn{7}{|c|}{ Carcass gain $(\mathrm{g} / \mathrm{d}) \dagger$} \\
\hline 0 & 434 & - & - & - & - & - \\
\hline 1 & 438 & 437 & 437 & 450 & 442 & 453 \\
\hline 2 & 470 & 452 & 453 & 456 & 457 & 485 \\
\hline 3 & 488 & 485 & 478 & 480 & 444 & 478 \\
\hline 4 & 502 & 463 & 488 & 467 & 468 & 485 \\
\hline 5 & 509 & 463 & 441 & 488 & 474 & 498 \\
\hline \multicolumn{7}{|c|}{ SEM $11 \cdot 4$} \\
\hline \multicolumn{7}{|c|}{ Food conversion efficiency (carcass basis) $\ddagger$} \\
\hline 0 & $0 \cdot 321$ & - & - & - & - & - \\
\hline 1 & 0.328 & $0 \cdot 319$ & 0.324 & $0 \cdot 337$ & $0 \cdot 327$ & $0 \cdot 336$ \\
\hline 2 & $0 \cdot 358$ & $0 \cdot 334$ & 0.334 & 0.345 & 0.341 & $0 \cdot 357$ \\
\hline 3 & $0 \cdot 367$ & 0.354 & 0.347 & 0.352 & 0.333 & 0.357 \\
\hline 4 & $0 \cdot 375$ & 0.348 & $0 \cdot 356$ & 0.339 & 0.353 & $0 \cdot 358$ \\
\hline 5 & 0.378 & $0 \cdot 346$ & 0.328 & $0 \cdot 357$ & $0 \cdot 348$ & $0 \cdot 370$ \\
\hline \multicolumn{7}{|c|}{ SEM 0.0074} \\
\hline \multicolumn{7}{|c|}{ Protein deposited $(\mathrm{g} / \mathrm{d}) \S$} \\
\hline 0 & $52 \cdot 8$ & - & - & - & - & - \\
\hline 1 & $61 \cdot 9$ & $54 \cdot 5$ & $55 \cdot 6$ & $61 \cdot 1$ & $56 \cdot 3$ & $60 \cdot 1$ \\
\hline 2 & $64 \cdot 0$ & $64 \cdot 9$ & $65 \cdot 2$ & $63 \cdot 6$ & $59 \cdot 3$ & $64 \cdot 6$ \\
\hline 3 & $67 \cdot 7$ & $70 \cdot 8$ & $66 \cdot 2$ & $66 \cdot 6$ & $60 \cdot 1$ & $69 \cdot 2$ \\
\hline 4 & $72 \cdot 3$ & $69 \cdot 0$ & $68 \cdot 8$ & $63 \cdot 8$ & $61 \cdot 6$ & $68 \cdot 5$ \\
\hline 5 & $73 \cdot 9$ & $70 \cdot 1$ & $63 \cdot 1$ & $73 \cdot 1$ & $62 \cdot 3$ & $68 \cdot 3$ \\
\hline \multicolumn{7}{|c|}{ SEM 3.44} \\
\hline
\end{tabular}

* For details, see p. 647.

$\dagger$ Hot carcass weight $(\mathrm{kg})$ - (initial live weight $(\mathrm{kg}) \times 0.69)$ : period (d) on experiment.

$\ddagger$ Hot carcass weight $(\mathrm{kg})$ - (initial live weight $(\mathrm{kg}) \times 0.69)$ : food intake $(\mathrm{kg})$.

$\S$ Protein in carcass $(\mathrm{kg})-[$ (initial live weight $(\mathrm{kg}) \times 0.69) \times 0.164$ (males) or 0.152 (females)]:period (d) on experiment.

\section{RESULTS}

Expt 1. Slope-ratio assay for lysine availability

Performance results of the pigs are presented in Tables 3-5. All pigs remained healthy throughout the experiment, although there was a small amount of food rejection by most pigs.

The level of inclusion of protein concentrate depressed killing-out proportion in the pigs given the three lupin-seed meals $(P<0.05)$. The proportion of energy retained in the carcasses was unaffected by the standard lysine doses or inclusion levels of soya-bean meal. Energy retention was significantly less $(P<0.05)$ with the three lupin-seed meals and the meat-and-bone meal.

With lupin-seed meal no. 2, in the slope-ratio analyses for daily carcass gain and FCE on a carcass basis, there was significant curvilinearity $(P<0.05)$. An examination of the results indicated depressed performance with the highest inclusion level $(200 \mathrm{~g} / \mathrm{kg})$. This 
Table 5. Expt 1. Protein deposited:food intake and energy deposited: digestible energy intake by pigs during the $20-45 \mathrm{~kg}$ growth phase when given the diets for the slope-ratio assay for lysine

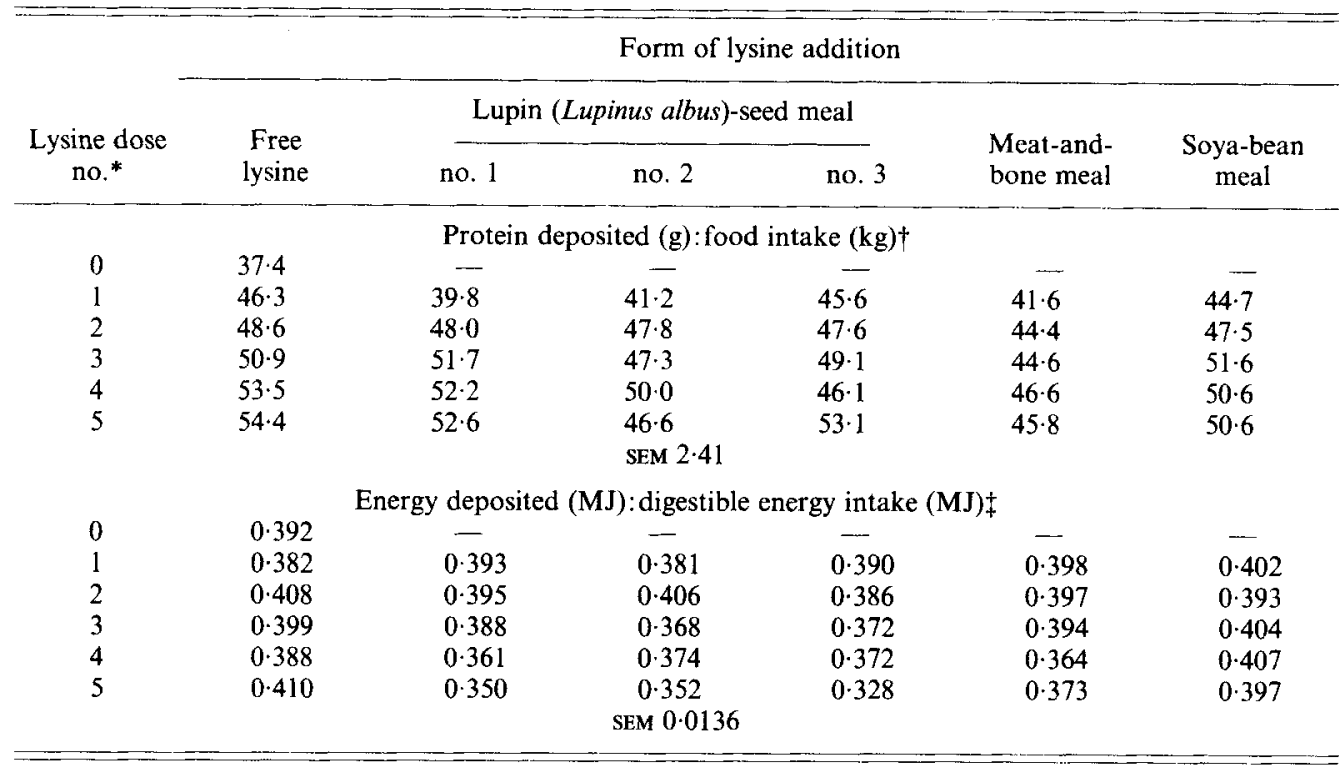

* For details, see p. 647.

$\dagger$ Crude protein (nitrogen $\times 6.25)$ in carcass $(\mathrm{g})-[$ (initial live weight $(\mathrm{kg}) \times 0.69) \times 0 \cdot 164$ (males) or $0 \cdot 152$ (females)]: food intake $(\mathrm{kg})$.

$\ddagger$ Energy in carcass $(\mathrm{MJ})-[$ (initial live weight $\times 0.69) \times 0.118$ (males) or 0.141 (females)]: digestible energy intake (MJ).

level was deleted from the analyses and the slope-ratio estimates were then statistically valid (Table 6).

Using FCE on a carcass basis as the criterion of response, availability was low in the three lupin-seed meals $(0.44-0.57)$ and meat-and-bone meal $(0.42)$ and high in the soya-bean meal $(0 \cdot 80)$.

When protein deposited/d or protein deposited: food intake were used as the measures of response, availability was higher in the three lupin-seed meals, lower in meat-and-bone meal and similar in soya-bean meal. Standard deviations were higher $(0 \cdot 14-0 \cdot 16)$ than those of estimates based on FCE on a carcass basis $(0 \cdot 10-0 \cdot 11)$.

When the measures of response were regressed $v$. lysine intake (Table 7), blanks were significant $(P<0.01)$ in both analyses, and there were significant intercept or curvature with three meals. Availability estimates and standard deviations were generally higher than those for the slope-ratio analyses.

\section{Expt 2. Effect of autoclaving and energy supplementation}

All pigs appeared healthy, although minor food rejection occurred with most pigs in the early stages of the experiment.

There were no differences in initial and final live weights, live-weight gains or days on experiment (Table 8). Killing-out proportion was significantly $(P<0.05)$ lower for pigs fed on diets containing lupin-seed meal relative to soya-bean meal. As a consequence, carcass gains were significantly greater and FCE higher in pigs fed on the soya-bean meal diet. 
Table 6. Expt 1. Availability of lysine (proportion of total) in the protein concentrates as assessed by the slope-ratio analysis regressing the indices of response v. lysine dose level

(Mean values and standard deviations)

\begin{tabular}{|c|c|c|c|c|c|c|c|c|}
\hline \multirow[b]{2}{*}{ Protein concentrate } & \multicolumn{2}{|c|}{$\begin{array}{l}\text { Daily carcass } \\
\text { gain }\end{array}$} & \multicolumn{2}{|c|}{$\begin{array}{l}\text { Carcass gain: } \\
\text { food intake }\end{array}$} & \multicolumn{2}{|c|}{$\begin{array}{c}\text { Protein } \\
\text { deposited/d }\end{array}$} & \multicolumn{2}{|c|}{$\begin{array}{l}\text { Protein } \\
\text { deposited:food } \\
\text { intake }\end{array}$} \\
\hline & Mean & SD & Mean & SD & Mean & SD & Mean & SD \\
\hline \multicolumn{9}{|c|}{ Lupin (Lupinus albus)-seed meal: } \\
\hline No. 1 & 0.48 & $0 \cdot 12$ & 0.44 & $0 \cdot 10$ & 0.86 & $0 \cdot 16$ & 0.82 & $0 \cdot 15$ \\
\hline No. 2 & 0.79 & $0 \cdot 14$ & 0.57 & $0 \cdot 11$ & 0.87 & 0.19 & 0.73 & $0 \cdot 16$ \\
\hline No. 3 & 0.66 & $0 \cdot 12$ & 0.53 & $0 \cdot 10$ & 0.78 & $0 \cdot 16$ & 0.70 & $0 \cdot 14$ \\
\hline Meat-and-bone meal & 0.45 & $0 \cdot 12$ & 0.42 & $0 \cdot 10$ & 0.29 & $0 \cdot 15$ & 0.27 & 0.14 \\
\hline Soya-bean meal & 0.87 & $0 \cdot 13$ & $0 \cdot 80$ & $0 \cdot 11$ & 0.81 & $0 \cdot 16$ & 0.77 & 0.15 \\
\hline
\end{tabular}

Table 7. Expt 1. Availability of lysine (proportion of total) in the protein concentrates as assessed by regressing the measures of response against lysine intake

(Mean values and standard deviations)

\begin{tabular}{|c|c|c|c|c|}
\hline \multirow[b]{2}{*}{ Protein concentrate } & \multicolumn{2}{|c|}{ Daily carcass gain* $(g)$} & \multicolumn{2}{|c|}{ Protein deposited/ $\mathrm{d}^{*}$} \\
\hline & Mean & SD & Mean & SD \\
\hline \multicolumn{5}{|c|}{ Lupin (Lupinus albus)-seed meal: } \\
\hline No. 1 & $0 \cdot 71$ & $0 \cdot 16$ & $-\dagger$ & - \\
\hline No. 2 & 0.78 & 0.15 & $-\dagger$ & - \\
\hline No. 3 & $0 \cdot 82$ & $0 \cdot 14$ & $-\dagger$ & - \\
\hline Meat-and-bone meal & 0.71 & $0 \cdot 16$ & 0.67 & $0 \cdot 14$ \\
\hline Soya-bean meal & 1.06 & 0.13 & 0.98 & $0 \cdot 11$ \\
\hline
\end{tabular}

* Blanks significant $(P<0 \cdot 01)$.

$\dagger$ Availability estimates invalid as intersection (meal nos. 1 and 2$)$ and curvature were significant $(P<0 \cdot 05)$.

Autoclaving lupin-seed meal had no effect on growth performance. The addition of oil resulted in higher FCE on both a live weight and carcass basis $(P<0.01)$.

There were no differences in the protein contents of the carcasses of pigs given lupin-seed meal or soya-bean meal (Table 9). However, protein deposition/d was lower for the pigs given lupin-seed meal $(P<0.05)$. Autoclaving lupin seed had no effect on protein deposition, whereas the addition of oil depressed it $(P<0.01)$.

Fat in the carcass was greater in pigs given soya-bean meal relative to lupin-seed meal $(P<0.05)$ (Table 10). Autoclaving had no effect on fat deposition. The addition of oil increased fat deposition in pigs given lupin-seed meal $(P<0.01)$.

Less energy was retained in the carcasses of pigs given lupin-seed meal relative to those given soya-bean meal (Table 11). The addition of oil to the diets containing lupin-seed meal increased energy deposition/d $(P<0.01)$. However, the ratio, energy deposited:digestible energy intake was significantly greater in pigs given soya-bean meal relative to those given lupin-seed meal with additional oil supplementation $(P<0.01)$. 
Table 8. Expt 2. Effect of autoclaving lupin (Lupinus albus) seed at $121^{\circ}$ for $5 \mathrm{~min}$, addition of oil, or both, on the growth performance of pigs given diets containing lupin-secd meal relative to that produced by pigs given soya-bean meal $\dagger$

\begin{tabular}{|c|c|c|c|c|c|c|c|c|c|c|}
\hline \multirow{3}{*}{ Diet no.... } & \multirow[b]{3}{*}{ Lupin } & \multirow[b]{2}{*}{2} & \multirow[b]{2}{*}{3} & \multirow[b]{2}{*}{4} & \multirow[b]{2}{*}{5} & \multicolumn{5}{|c|}{ Statistical significance } \\
\hline & & & & & & \multicolumn{3}{|c|}{$\begin{array}{l}\text { Factorial } \\
\text { (diets 1-4) }\end{array}$} & & \multirow[b]{2}{*}{ SEM } \\
\hline & & $\begin{array}{c}\text { Heated } \\
\text { lupin }\end{array}$ & $\begin{array}{l}\text { Lupin } \\
\text { +oil }\end{array}$ & $\begin{array}{l}\text { Heated } \\
\text { lupin } \\
+ \text { oil }\end{array}$ & $\begin{array}{c}\text { Soya- } \\
\text { bean }\end{array}$ & Heat & Oil & $\begin{array}{l}\text { Heat } \\
\times \text { oil }\end{array}$ & $\begin{array}{l}\text { diets } \\
\text { LSD } \\
P=0-05\end{array}$ & \\
\hline Initial weight $(\mathrm{kg})$ & $20 \cdot 4$ & $20 \cdot 3$ & $20 \cdot 2$ & $20 \cdot 3$ & $20 \cdot 3$ & NS & NS & NS & NS & $0 \cdot 14$ \\
\hline Final weight (kg) & $46 \cdot 7$ & $46 \cdot 9$ & $46 \cdot 6$ & $46 \cdot 1$ & $46 \cdot 8$ & NS & NS & NS & NS & 0.46 \\
\hline Weight gain $(\mathrm{kg})$ & $26 \cdot 3$ & $26 \cdot 6$ & $26 \cdot 3$ & $25 \cdot 8$ & $26 \cdot 6$ & NS & NS & NS & NS & $0 \cdot 48$ \\
\hline Period on experiment (d) & $43 \cdot 4$ & $45 \cdot 4$ & $43 \cdot 3$ & $42 \cdot 6$ & $41 \cdot 8$ & NS & NS & NS & NS & 0.93 \\
\hline Gain $(g / d)$ & 607 & 587 & 609 & 608 & 636 & NS & NS & NS & 29 & $10 \cdot 1$ \\
\hline Food intake $(\mathrm{kg})$ & $55 \cdot 6$ & $58 \cdot 8$ & $54 \cdot 4$ & $54 \cdot 2$ & $56 \cdot 1$ & NS & $*$ & NS & NS & 1.38 \\
\hline $\begin{array}{l}\text { Food conversion } \\
\text { efficiency (FCE) }\end{array}$ & 0.466 & 0.453 & 0.485 & 0.477 & 0.475 & NS & $* *$ & NS & 0.022 & 0.0075 \\
\hline Killing-out proportion & 0.710 & 0.712 & 0.703 & 0.716 & 0.752 & NS & NS & NS & 0.016 & 0.0055 \\
\hline Carcass gain $(\mathrm{kg})$ & $19 \cdot 1$ & $19 \cdot 4$ & $18 \cdot 8$ & $19 \cdot 1$ & $21 \cdot 2$ & NS & NS & NS & $1 \cdot 10$ & $0 \cdot 38$ \\
\hline Carcass gain $(\mathrm{g} / \mathrm{d})$ & 440 & 429 & 434 & 447 & 508 & NS & NS & $*$ & 17 & $6 \cdot 1$ \\
\hline FCE (carcass basis) & 0.338 & 0.330 & 0.345 & $0 \cdot 351$ & $0 \cdot 380$ & NS & $* *$ & NS & 0.014 & 0.0049 \\
\hline Backfat $\left(P_{2}, \mathrm{~mm}\right)$ & $11 \cdot 4$ & $11 \cdot 3$ & 12.9 & $12 \cdot 4$ & $14 \cdot 2$ & NS & NS & NS & 1.9 & 0.67 \\
\hline
\end{tabular}

LSD, least significant difference; NS, not significant.

${ }^{*} P<0.05,{ }^{* *} P<0.01$. † For details of measurements, see p. 649.

Table 9. Expt 2. Effect of autoclaving lupin (Lupinus albus) seed at $121^{\circ}$ for $5 \mathrm{~min}$, addition of oil, or both, on protein deposition of pigs given diets containing lupin-seed meal relative to that produced by pigs given soya-bean meal $\dagger$

\begin{tabular}{|c|c|c|c|c|c|c|c|c|c|c|}
\hline \multirow{3}{*}{ Diet no.... } & \multirow[b]{3}{*}{ Lupin } & \multirow[b]{2}{*}{2} & \multirow[b]{2}{*}{3} & \multirow[b]{2}{*}{4} & \multirow[b]{2}{*}{5} & \multicolumn{5}{|c|}{ Statistical significance } \\
\hline & & & & & & \multicolumn{3}{|c|}{$\begin{array}{l}\text { Factorial } \\
\text { (diets } 1-4)\end{array}$} & \\
\hline & & $\begin{array}{l}\text { Heated } \\
\text { lupin }\end{array}$ & $\begin{array}{l}\text { Lupin } \\
\text { +oil }\end{array}$ & $\begin{array}{c}\text { Heated } \\
\text { lupin } \\
\text { +oil }\end{array}$ & $\begin{array}{l}\text { Soya- } \\
\text { bean }\end{array}$ & Heat & Oil & $\begin{array}{l}\text { Heat } \\
\times \text { oil }\end{array}$ & $\begin{array}{c}\text { diets } \\
\text { LSD } \\
P=0.05\end{array}$ & SEM \\
\hline $\begin{array}{l}\text { Protein in carcass } \\
(\mathrm{g} / \mathrm{kg})\end{array}$ & 158 & 157 & 154 & 149 & 155 & NS & $* *$ & NS & 6 & $2 \cdot 2$ \\
\hline Protein deposited $(\mathrm{kg})$ & $3 \cdot 02$ & 3.03 & $2 \cdot 82$ & $2 \cdot 70$ & $3 \cdot 26$ & NS & $* *$ & NS & $0 \cdot 27$ & 0.095 \\
\hline Protein deposited $(\mathrm{g} / \mathrm{d})$ & 70 & 67 & 65 & 63 & 78 & NS & NS & NS & 6 & $2 \cdot 0$ \\
\hline $\begin{array}{l}\text { Protein deposited }(\mathrm{kg}) \text { : } \\
\text { food intake }(\mathrm{kg})\end{array}$ & 54 & 51 & 52 & 50 & 59 & NS & NS & NS & 5 & $1 \cdot 7$ \\
\hline $\begin{array}{l}\text { Protein deposited }(\mathrm{g}) \text { : } \\
\text { digestible energy } \\
\text { intake (MJ) }\end{array}$ & $3 \cdot 7$ & $3 \cdot 5$ & $3 \cdot 4$ & $3 \cdot 3$ & $4 \cdot 1$ & NS & $*$ & NS & 0.3 & $0 \cdot 11$ \\
\hline
\end{tabular}

LSD, least significant difference; NS, not significant.

${ }^{*} P<0.05,{ }^{* *} P<0.01$. † For details of measurements, see p. 649. 
Table 10. Expt 2. Effect of autoclaving lupin (Lupinus albus) seed at $121^{\circ}$ for 5 min, addition of oil, or both, on fat deposition of pigs given diets containing lupin-seed meal relative to that produced by pigs given soya-bean meal $\dagger$

\begin{tabular}{|c|c|c|c|c|c|c|c|c|c|c|}
\hline \multirow{3}{*}{ Diet no.... } & \multirow[b]{3}{*}{ Lupin } & \multirow[b]{2}{*}{2} & \multirow[b]{2}{*}{3} & \multirow[b]{2}{*}{4} & \multirow[b]{2}{*}{5} & \multicolumn{5}{|c|}{ Statistical significance } \\
\hline & & & & & & \multicolumn{3}{|c|}{$\begin{array}{c}\text { Factorial } \\
\text { (diets 1-4) }\end{array}$} & & \multirow[b]{2}{*}{ SEM } \\
\hline & & $\begin{array}{l}\text { Heated } \\
\text { lupin }\end{array}$ & $\begin{array}{l}\text { Lupin } \\
\text { +oil }\end{array}$ & $\begin{array}{l}\text { Heated } \\
\text { lupin } \\
+ \text { oil }\end{array}$ & $\begin{array}{l}\text { Soya- } \\
\text { bean }\end{array}$ & Heat & Oil & $\begin{array}{r}\text { Heat } \\
\times \text { oil }\end{array}$ & $\begin{array}{l}\text { diets } \\
\text { LSD } \\
P=0.05\end{array}$ & \\
\hline Fat in carcass $(\mathrm{g} / \mathrm{kg})$ & 200 & 220 & 237 & 237 & 232 & NS & ** & NS & 17 & 6 \\
\hline Fat deposited (kg) & 4.81 & 5.55 & $5 \cdot 96$ & 6.02 & $6 \cdot 35$ & NS & $* *$ & NS & 0.67 & 0.234 \\
\hline Fat deposited $(\mathrm{g} / \mathrm{d})$ & 111 & 123 & 138 & 141 & 152 & NS & $* *$ & NS & 13 & $4 \cdot 4$ \\
\hline $\begin{array}{l}\text { Fat deposited }(\mathrm{kg}) \text { : } \\
\text { food intake }(\mathrm{kg})\end{array}$ & 0.085 & 0.095 & $0 \cdot 110$ & 0.111 & $0 \cdot 113$ & NS & $* *$ & NS & 0.010 & 0.0034 \\
\hline $\begin{array}{l}\text { Fat deposited }(\mathrm{g}) \text { : } \\
\text { digestible energy } \\
\text { intake }(\mathrm{MJ})\end{array}$ & $5 \cdot 88$ & $6 \cdot 52$ & $7 \cdot 21$ & $7 \cdot 29$ & $7 \cdot 87$ & NS & $* *$ & NS & 0.7 & $0 \cdot 230$ \\
\hline
\end{tabular}

LSD, least significant difference; NS, not significant.

${ }^{*} P<0.05,{ }^{* *} P<0.01$. † For details of measurements, see p. 649 .

Table 11. Expt 2. Effect of autoclaving lupin (Lupinus albus) seed at $121^{\circ}$ for 5 min, addition of oil, or both, on energy deposition of pigs given diets containing lupin-seed meal relative to that produced by pigs given soya-bean meal $\dagger$

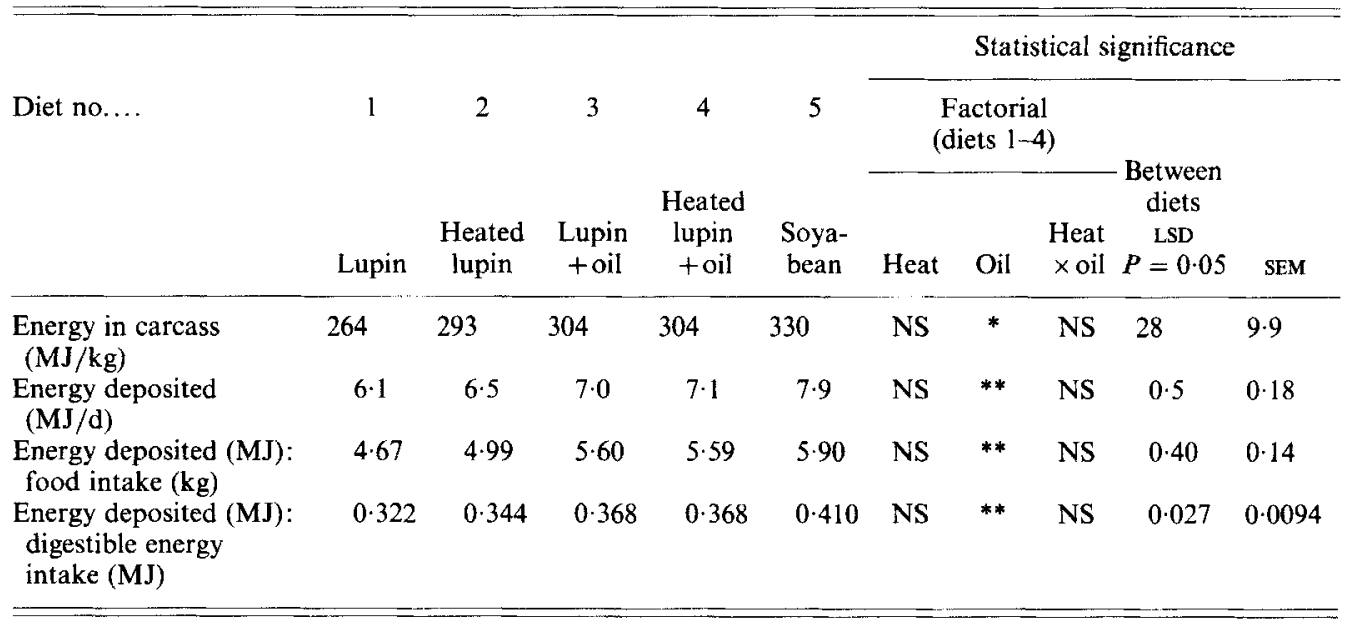

LSD, least significant difference; NS, not significant.

${ }^{*} P<0.05,{ }^{* *} p<0.01$. + For details of measurements, see p. 649. 


\section{DISCUSSION}

\section{Expt 1. Slope-ratio assay for lysine availability}

The availability estimates based on FCE on a carcass basis as the index of response are similar to values reported previously. The low lysine availability of approximately 0.51 for $L$. albus seed meal is similar to the availability in cultivars of $L$. angustifolius reported by Batterham et al. (1984). The value of 0.80 for soya-bean meal is slightly lower than the estimates of 0.85 (Batterham et al. 1979) and 0.89 and 0.98 (Batterham et al. 1984), but is within the range anticipated considering the SD for the slope-ratio estimates is approximately $0 \cdot 10$. The low estimate of 0.42 for meat-and-bone meal is slightly lower than the range of estimates, 0.48 to 0.88 , for commercial meat-and-bone meals (Batterham et al. $1986 b$ ).

The differences in estimates of availability when the results were assessed on a protein rather than a carcass basis (Table 6) is unusual. For three meals (the lupin-seed meals) the values were higher and for the remainder (meat-and-bone meal and soya-bean meal) lower. When energy intake is controlled and lysine limiting, growth response and protein deposition should be related to lysine intake. Increasing the lysine level increases the lysine:energy ratio which should increase lean deposition and growth rate. Therefore, availability estimates based on both measures should be similar. This may not apply to assays conducted with ad lib. feeding when differences in food intake may develop between treatments.

Although there were differences in the energy retained:digestible energy intake, this did not appear to affect the results. With the lupin-seed meals, the estimates based on protein deposition were higher and, for meat-and-bone meal, lower. If there was less energy available for metabolism, protein deposition would have been retarded to a greater extent than fat deposition, as less energy is needed for protein deposition. The estimates based on protein deposition had considerably higher standard deviations $(0 \cdot 14-0 \cdot 16)$ than those based on carcass deposition $(0 \cdot 10-0 \cdot 11)$. These differences in standard deviations may be the reason for the lack of agreement between the two sets of estimates. That carcass estimates seem more appropriate is also supported by the results for protein deposition in Expt 2 (see p. 654). The greater variation in the estimates based on protein deposition is in agreement with the findings of Cave \& Williams (1980), who reported unacceptably high fiducial limits when carcass nitrogen gain was compared with weight gain.

There appeared to be no advantage in assessing availability by regressing the measure of response $v$. lysine intake. Availability estimates and standard deviations were generally higher. In addition, invalidity due to blanks and curvature was a greater problem than with the conventional slope-ratio analysis. These findings are in contrast to the results of Cave $\&$ Williams (1980), who reported fundamental invalidity in two assays using slope-ratio analysis which were not a problem when the values were regressed $v$. lysine intake.

The indirect fluorodinitrobenzene-lysine values for the five protein concentrates were high (Table 1), ranging from 0.80 in meat-and-bone meal to 0.96 in lupin-seed meal. These values are consistent with earlier results (Batterham et al. 1984, 1986 a) and indicate that reactions involving the $\epsilon$-amino group of lysine do not appear to be the reason for the reduced availability in the lupin-seed meals and meat-and-bone meal.

\section{Expt 2. Effect of autoclaving and energy supplementation}

The depressing effects of the oil supplementation on protein deposition in pigs given the diets containing lupin-seed meal (Table 9) indicate that the diets were adequate in energy. The addition of energy to a diet already adequate in energy, but deficient in lysine, would widen the energy:lysine value even further and depress protein utilization. The increased 
fat deposition in the pigs given the energy-supplemented diets (Table 10) indicates that part of the extra energy consumed under the controlled feeding system was stored as fat. Part of this energy may also have been used for the higher maintenance cost associated with the depressed protein utilization. The adequacy of the diets in terms of energy indicates that the digestible energy values used to formulate the diets were applicable for these food sources. Therefore a deficiency of energy was unlikely to have been the reason for the low availability of lysine in the lupin-seed meals recorded in Expt 1 nor in the previous slope-ratio assays of Batterham et al. (1984).

The lower energy retention of pigs given lupin-seed meal $(0 \cdot 32)$ relative to those given soya-bean meal $(0 \cdot 41)$ (Table 11) appears to be due, in part, to a higher maintenance cost in these pigs as a result of the slower growth. Although the live-weight gains of pigs on all diets were similar (Table 8), pigs given lupin-seed meal accumulated digesta in the hind-gut which lowers the killing-out proportion and, thus, carcass gains. Therefore, the maintenance energy cost per unit of carcass gain would be higher than for those pigs fed on the diet containing soya-bean meal. In addition, there would also be a higher energy cost associated with catabolizing surplus amino acids in the lupin-seed-meal diet as a consequence of the lysine deficiency. This cost may also have been the reason for the lower energy retention by pigs given the diets containing lupin-seed meal and meat-and-bone meal in Expt 1.

The adequacy of the diets in terms of net energy also indicates that the equations for predicting net energy, developed by Just et al. (1983) and Taverner \& Curic (1983), are not applicable to diets containing lupin-seed meal for growing pigs. Lupin-seed meal is unusual in that, although it has a high fibre content (Table 1), pigs are able to digest this fibre. Although this digestion appears to occur in the hind-gut (Taverner et al. 1983), the results of the present study indicate that the efficiency of energy absorption appears to be similar to that based on digestion in the small intestine. Consequently, prediction equations developed with foods containing conventional fibre sources, which are normally poorly digested, are unlikely to apply.

The lack of response to autoclaving the lupin seed indicates that there were no heat-labile anti-nutritional factors in the sample of $L$. albus meal. The tolerance to the $370 \mathrm{~g} / \mathrm{kg}$ inclusion is similar to that of pigs fed on cultivars of L. angustifolius. The lower growth rate appears to be due to the lower lysine availability in the meal. This may also have been the reason for the lower growth performance recorded in earlier studies with cultivars of L. albus (Batterham, 1979; King, 1981; Taverner, 1982).

The diets for Expt 2 were formulated on a total lysine basis. However, if one applies the availability estimates from Table 6 to the diets used in Expt 2, then the available lysine contents $(\mathrm{g} / \mathrm{kg}$ diet) of the lupin-seed and soya-bean meal diets (diets 1 and 5) were as follows:

$\begin{array}{lcc} & \text { Diet } 1 & \text { Diet } 5 \\ \text { Based on carcass gain:food intake* } & 5 \cdot 0 & 6 \cdot 5 \\ \text { Based on protein deposition:food intake* } & 6 \cdot 0 & 6 \cdot 3\end{array}$

* Assuming 0.85 ileal digestibility for the lysine in wheat.

In Expt 2, the soya-bean meal diet produced a significantly better rate of carcass weight gain (Table 8) and protein deposition (Table 9) in the pigs than did the lupin-seed diet. This indicates that the carcass gain: food intake estimates seem more appropriate as it is doubtful that the small differences in availability based on the protein deposition estimates would have resulted in significant differences in growth or protein deposition. 


\section{Lysine availability in lupin-seed meal}

The results of these experiments confirm earlier studies that the lysine in lupin-seed meal has a low availability for growing pigs. The reason for this has not been elucidated. It is specific to pigs as the availability of lysine for rats $(0 \cdot 82$; Batterham et al. 1984) and chicks $(0.89$; E. J. Major and E. S. Batterham, unpublished results) is high. The present study shows that it is not due to a lower net energy in the meal as a result of digestion of part of the energy in the hind-gut of pigs. The previous studies of heat treatment (Batterham et al. 1986a), together with the present results, indicate that it is not due to heat-labile anti-nutritional factors in the meal. It could be due to one of two factors. There may be an unidentified growth inhibitor in the meal. Such a factor would have to depress performance in a linear manner with increasing inclusion levels of lupin-seed meal. The factor would also have to act by depressing metabolism and not digestion as the ileal digestibility of lysine in the meals was high $(0.93$; Taverner et al. 1983). It is also interesting to note that the addition of free lysine to the diets containing lupin-seed meal did not completely overcome the differences in growth-promoting ability between lupin-seed and soya-bean meals (Batterham et al. 1986a). This supports the hypothesis that there may be an unidentified growth inhibitor present in the seed that depresses production. Alternatively, the low availability may be due to the lysine being in a form that is absorbed but inefficiently utilized. There is evidence that forms of lysine can vary in their nutritional value. For example, $\epsilon-N$-proprionyl-L-lysine has been shown to have no nutritional value for rats (Bjarnason \& Carpenter, 1969) but can be utilized by chicks (Varnish \& Carpenter, 1975). Rats absorb propionyl lysine as it is excreted in their urine (Bjarnason \& Carpenter, 1969) but lack the kidney enzyme, $\epsilon-N$-lysine acylase, which the chick has, to utilize it (Varnish $\&$ Carpenter, 1975). However, $\epsilon-N$-propionyl-L-lysine is a derivative of lysine produced by heat. For such a form of lysine to be present in lupin-seed meal, it would need to exist in the natural state as the meal is normally given raw.

The authors thank Messrs N. R. Thompson and A. W. Davis, Miss B. V. Burnham and Lesley Wilkins for management of the pigs and skilled technical assistance, and $\mathrm{Dr}$ M. R. Taverner, Animal Research Institute, Werribee, for the supply of lupin-seed meal no. 2. This work was supported by financial grants from the Australian Pig Industry Research Committee.

\section{REFERENCES}

Agricultural Research Council (1981). The Nutrient Requirements of Pigs. Farnham Royal: Commonwealth Agricultural Bureaux.

Association of Official Analytical Chemists (1975). Official Methods of Analysis of the Association of Official Analytical Chemists, 12th ed. Washington, DC: Association of Official Analytical Chemists.

Batterham, E. S. (1979). Australian Journal of Agricultural Research 30, 369-375.

Batterham, E. S., Andersen, L. M., Burnham, B. V. \& Taylor, G. A. (1986a). British Journal of Nutrition 55, 169-177.

Batterham, E. S., Lowe, R. F., Darnell, R. E. \& Major, E. J. (1986b). British Journal of Nutrition 55, 427-440.

Batterham, E. S. \& Murison, R. D. (1981). British Journal of Nutrition 46, 87-92.

Batterham, E. S., Murison, R. D. \& Andersen, L. M. (1984). British Journal of Nutrition 51, 85-99.

Batterham, E. S., Murison, R. D. \& Lewis, C. E. (1979). British Journal of Nutrition 41, 383-391.

Batterham, E. S., Murison, R. D. \& Lowe, R. F. (1981). British Journal of Nutrition 45, 401-410.

Bjarnason, J. \& Carpenter, K. J. (1969). British Journal of Nutrition 23, 859-868.

Burlacu, G., Baia, G., Ionila, D., Moisa, D., Tascenco, V., Visan, I. \& Stoica, I. (1973). Journal of Agricultural Science, Cambridge 81, 295-302.

Campbell, R. C. (1966). Biometrics 22, 58-73.

Carpenter, K. J. (1973). Nutrition Abstracts and Reviews 43, 423-451.

Cave, N. A. \& Williams, C. J. (1980). Poultry Science 59, 799-804.

Finney, D. J. (1964). Statistical Method in Biological Assay, 2nd ed. London: Griffin. 
Jordan, J. W. \& Brown, W. O. (1970). In Energy Metabolism of Farm Animals, pp. 161-164 [A. Schurch and C. Wenk, editors]. Zurich: Juris Druck and Verlag.

Just, A., Fernandez, J. A. \& Jorgensen, H. (1983). Livestock Production Science 10, 171-186.

King, R. H. (1981). Animal Feed Science and Technology 6, 285-296.

Pettinati, J. D. \& Swift, C. E. (1975). Journal of the Association of Official Analytical Chemists 58, $1182-1187$.

Priddis, C. R. (1983). Journal of Chromatography 261, 95-101.

Taverner, M. R. (1982). Proceedings of the Australian Society of Animal Production 14, 667.

Taverner, M. R. \& Curic, D. M. (1983). In Feed Information and Animal Production, pp. 295-298 [G. E. Robards and R. G. Packham, editors]. Slough: Commonwealth Agricultural Bureaux.

Taverner, M. R., Curic, D. M. \& Rayner, C. J. (1983). Journal of the Science of Food and Agriculture 34, $122-128$.

Varnish, S. A. \& Carpenter, K. J. (1975). British Journal of Nutrition 34, 325-337. 